\title{
COMPOSITION AND STRUCTURE OF THE INVERTEBRATE FAUNA IN LITTORAL SANDY SHORES OF LAKE BRACCIANO (CENTRAL ITALY) AND WATER QUALITY MONITORING.
}

\author{
L. Mastrantuono \\ Department of Animal and Human Biology, Viale dell'Universita 32,00185 Rome, (Italy).
}

Palabras clave: litorales arenosos, estructuras zoobentos, biomonitorización, lagos.

Keywords: sandy shores, zoobenthos, composition, biomonitoring, lake.

\begin{abstract}
The invertebrate fauna associated with littoral sandy substrata in the volcanic Lake Bracciano (Italy), utilized as water supply for the city of Rome, was analysed for one year in twelve sampling stations distributed along the entire lacustrine perimeter. The zoocoenosis comprised 103 identified taxa mainly belonging to oligochaetes, chironomids, nematodes and cladocerans. Oligochaetes and nematodes accounted for most of the collected organisms (76\%), followed by a high proportion of copepods (13\%). Several other smaller but important groups ensured the diversification of the community. The analysis of a series of simple parameters (diversity indices, N/T ratio, densities of bioindicator taxa), that previous investigations revealed as useful for quality monitoring, provided a diagnosis of acceptable water quality in the marginal area of the lake, and contributed to indicating a mesotrophic condition.
\end{abstract}

\section{INTRODUCTION}

Lake Bracciano is one of the largest $\left(51 \mathrm{~km}^{2}\right)$ and deepest (max. depth: $165 \mathrm{~m}$ ) italian lakes, located in the volcanic area in the northern part of Lazio Region. The utilization of the lake as a water supply for the city of Rome dates back to ancient times (Emperor Trajan's Aqueduct, built in 110 A.D.). This aqueduct, used uninterruptedly up to the present, has been periodically restored and, during the XVIIIth century, enriched with superficial lacustrine waters in order to compensate for a decrease of the flow. In recent years (1968) the water is purified to make it drinkable in the Rome area. This utilization plan made it necessary, in the years ' $82-' 84$, to construct around the lake an o-ring collector of wastes of the surrounding villages. This sewerage system, connected with a sewage treatment plant (BRUNO, 1985; MARTINI, 1985), discharges the waters into the Arrone river, the only effiuent of the lake.

In spite of the absence of substantial organic discharges and of industrial activities along the shores, the presence of some cultivated areas, the increasing use for tourist purposes of the larger sandy beaches and the existence of several inlets discharging into the lake also wastes of private buildings not connected to the sewarege system, represent elements of local microdeterioration of water quality which call for environmental monitoring especially in the littoral, directly subjected to possible pollution phenomenon. Moreover, it must be stressed that the low turnover time of the water (137 years, one of the highest times so far calculated in Italian lakes, GAGGINO et al., 1985), could cause serious problems of lake recovery in the case of heavy pollution.

Given the importance of Lake Bracciano from numerous points of view and also considering its unquestionable role for fishing activities, the small number of papers on its lacustrine fauna is somewhat surprising. The first analyses (LOSITO, 1904; SOMMANI, 1961) referred only to the zooplanktonic community, while multidisciplinary research was carried out in the years 1970-71 by the Hydrobiological Institute of Pallanza (northern Italy) regarding both the chemical and the biological aspects (BARBANTI et al., 1971). The results indicated a good water quality, which was partially confirmed by investigations carried out later by different authors on zooplankton (FERRARA,1982), littoral and profundal macrobenthos (BAZZANTI, 1981) and physico-chemical analyses (GAGGINO et al., 1985).

Such a picture suggested the advisability of undertaking a first analysis of the zoobenthos associated with littoral sand, a community that had already been object of a series of investigations in different lakes of Central Italy (Nemi, Vico, Albano). These studies (MASTRANTUONO, 1986; MASTRANTUONO \& LA ROCCA, 1988; MASTRANTUONO, 
1995) carried out using the same method and plan in order to facilitate comparison of results, have so far adressed at two aspects: the first aimed at the qualitative characterization of the community (a total of about 200 species have so far been identified), the other one to identify parameters (especially bioindices and boindicators) useful in an environmental diagnosis of both different littoral sites and the marginal lacustrine area as a whole. The results so far obtained have also proved how this type of monitoring can provide valid support for the evaluation of quality status of the entire water body.

\section{STUDY AREA, MATERIALS AND METHODS}

Lake Bracciano is located at a height of $164 \mathrm{~m}$ a.s.l. in Central Italy (North of Rome). Most of the lacustrine perimeter $(31.5 \mathrm{~km})$ is characterized by a week bottom slope and the presence of large sandy zones (Fig. 1) used for bathing activities (the localities of Anguillara, Vigna di Valle, Quarto del lago, Bracciano, Trevignano).

Limited farming activities are carried in the areas of Bagni di Vicarello and Acquarella around the lake. The pipeline of the Paolo-Traiano aqueduct that draws water at a depth of about $50 \mathrm{~m}$ is located at station 12 (Fig. 1).

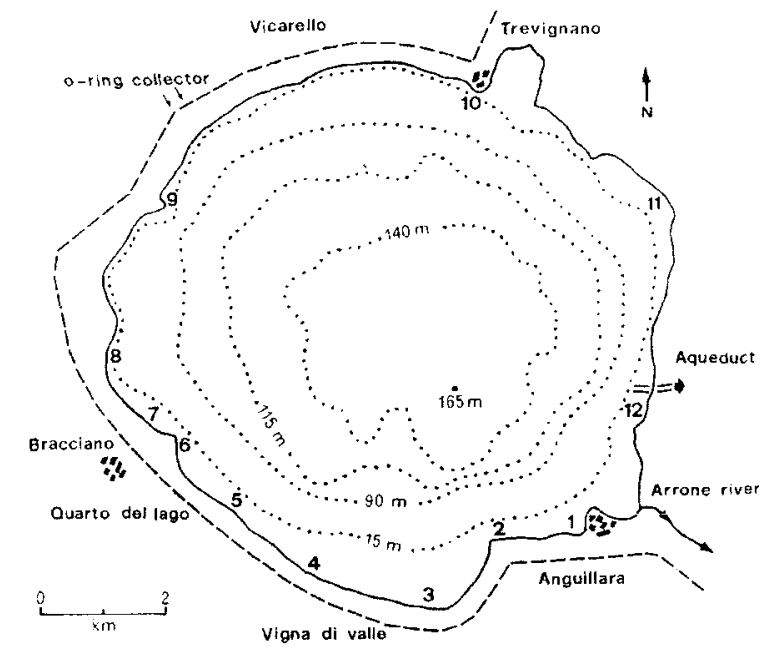

FIGURE 1. Map of Lake Bracciano and location of the sampling satıons.

Littoral sandy sediments were collected bimonthly from July 1989 to July 1990 in 12 stations distributed along the entire lacustrine perimeter (Fig. I). Three replicated samples for each station and date (total: 252 samples) were taken at a depth of 0.5-1 m using a grab (surface area: $42 \mathrm{~cm}^{2}$ ) made several years ago by a specialized laboratory (Thalassia Trieste) according to our indications. 168 samples were used for fauna analysis, the remaining ones for grain size analysis of the sediments. The samples utilized for fauna analysis were preserved in $10 \%$ formalin, coloured with bengal rosa and filtered through a net with a mesh size of $180 \mathrm{llm}$ in order to reduce fine sediments. All the invertebrates were then sorted under a stereomicroscope at low magnification. Only when necessary subsamples representing $1 / 2$ or $1 / 4$ of the entire sample were also made.

Numerical data of the two replicated samples for each date and station were averaged. The following indices were applied to the annual mean values: Shannon diversity (MARGALEF, 1957), evenness (PIELOU, 1966), quantitative similarity (PSc, RENKONEN, 1938). PSc data were represented by UPGMA clustering method (SNEATH \& SOKAL, 1973).

In order to analyse grain size composition, the samples referring to each station and date (each sample corresponding to $250 \mathrm{gr}$.) were sieved through the following mesh sizes: $10 \mathrm{~mm}, 5 \mathrm{~mm}, \mathrm{Imm}, 0.5 \mathrm{~mm}, 0.25 \mathrm{~mm},<0.25 \mathrm{~mm}$. The grain size categories were dried at 60 " $\mathrm{C}$ for twelve hours to obtain the dry weight. The obtained values were grouped in only four categories to simplify data interpretation.

\section{RESULTS}

\section{Physico-chemical characteristics}

Temperature and $\mathrm{pH}$ values were measured at each date of sampling only in a single station (st. 9). Over the investigation period temperature varied from a minimum of $9^{\circ} \mathrm{C}$ (January 1990) to a maximum of $27^{\circ} \mathrm{C}$ (July 1990, Fig. 2), a typical range of variation of surface waters in our regions. Basic $\mathrm{pH}$

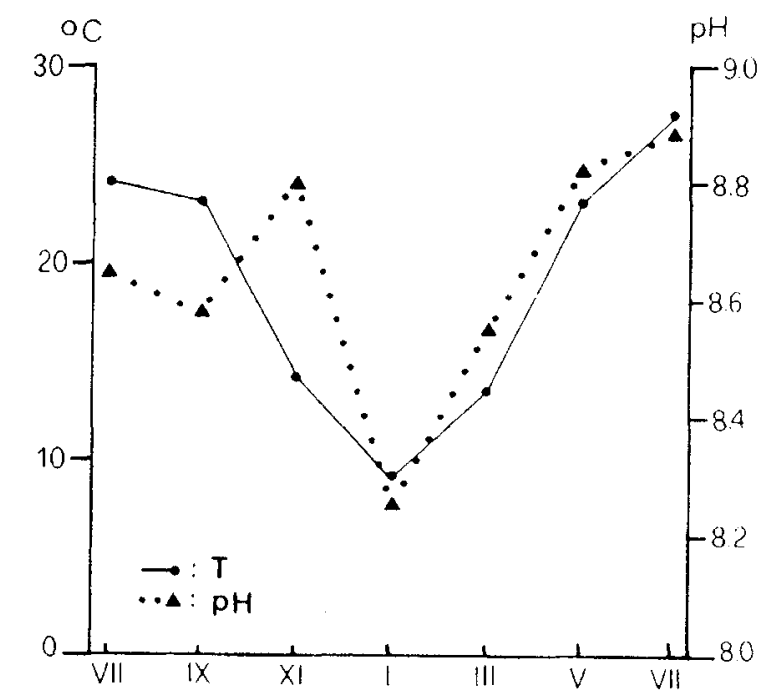

FIGURE 2. Seasonal variations of temperature and $\mathrm{pH}$ 
values were observed in all seasons, with minimum values in winter according to the trend of the temperature (Fig. 2).

The grain size composition at the sampling stations (Fig. 3) showed a quantitative dominance of fine gravel (5-1 mm) and coarse sand (1-0.25 mm) (according to WEBER's classification, 1973) in the majority of the stations $(1,2,3,4$, $6,8,11,12)$. High proportion of fine material were found primarily at st. 9 and secondly at stations 7 and 6. Only st. 8

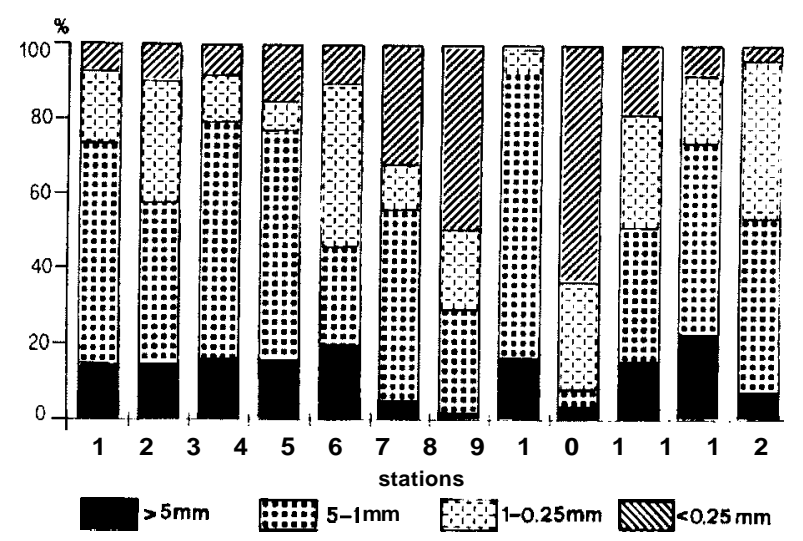

FIGURE 3. Grain size composition (annual means) at the sampling stations.

was characterized by negligible quantities of fine sediments and by high presence of coarse sand.

\section{Fauna composition}

The invertebrate fauna is composed of 15 zoological groups comprising a total of 103 identified taxa (63 species, 14 genera and 26 higher taxa, Tab. 3) belonging for the most part to oligochaetes (26 taxa), chironomids (19), nematodes (18) and cladocerans (1 1 ).

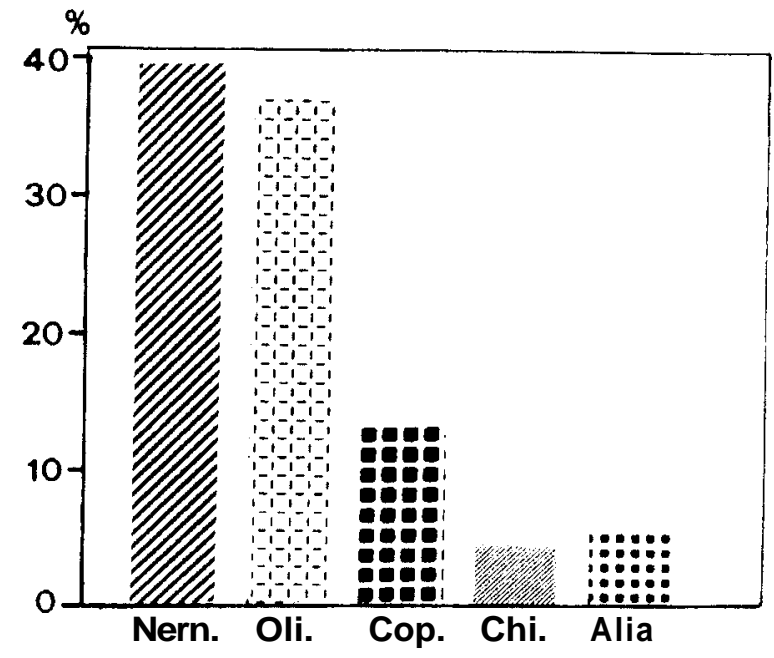

FIGURE 4. Percentage composition of the total fauna (cumulative data). Nem.: Nematoda; Oli.: Oligochaeta; Cop.: Copepoda; Chi.: Chironomidae.

As extensively documented in my previous investigations (MASTRANTUONO, 1986, MASTRANTUONO \& LA ROCCA, 1988; MASTRANTUONO, 1995, MASTRANTUONO \& BALDETTI, 1996a, 1996b), the community structure of lacustrine sandy substrata is strongly characterized by an Oligochaeta-Nematoda-Crustacea-Chironomidae association, followed by several faunal groups which represent a smaller but important component. In Lake Bracciano oligochaetes and nematodes, both characterized by a high degree of diversification, together represented about $76 \%$ of the total fauna (Fig. 4). These dominant groups are associated with a remarkable abundance of copepods (13\%), while chironomids, which generally represent a typical and important component of the sediment community, were found to be scarce $(5 \%)$.

Table 1 Annual mean densities (ind. $\mathrm{m}^{2}$ ) of the zoological groups found in littoral sand of Lake Bracciano

\begin{tabular}{|c|c|c|c|c|c|c|c|c|c|c|c|c|}
\hline Stations & 1 & 2 & 3 & 4 & 5 & 6 & 7 & 8 & 9 & 10 & 11 & 12 \\
\hline Turbellaria & 1819 & 4641 & 102 & 374 & 1717 & 340 & 935 & 2618 & 544 & 629 & 1717 & 1513 \\
\hline Nematoda & 8908 & 2295 & 4624 & 16694 & 30107 & 2516 & 291652 & 2006 & 43775 & 9146 & 35003 & 1955 \\
\hline Oligochaeta & 13209 & 43367 & 3451 & 6409 & 140420 & 8602 & 107270 & 25959 & 9350 & 6987 & 31331 & 24752 \\
\hline Hirudinea & • & - & 17 & - & - & - & - & - & - & 17 & - & • \\
\hline Gastropoda & - & - & - & - & - & 17 & 221 & 102 & 119 & 68 & 102 & - \\
\hline Bivalvia & - & 17 & - & - & - & $\therefore$ & 34 & 17 & - & - & - & 51 \\
\hline Hydracarina & 204 & 17 & 289 & 119 & 595 & 5066 & 272 & 663 & 2686 & 544 & 510 & 1377 \\
\hline Cladocera & 255 & 68 & 238 & 187 & 238 & 153 & 5695 & 340 & 136 & 663 & 2771 & 357 \\
\hline Copepoda & 2091 & 136 & 1700 & 1989 & 1224 & 4216 & 109599 & 5746 & 5202 & 6443 & 12240 & 1207 \\
\hline Ostracoda & 153 & 204 & 442 & 272 & 136 & 5151 & 10302 & 391 & 1037 & 306 & 629 & 1105 \\
\hline Amphipoda & - & 85 & 272 & 357 & 136 & 323 & 2465 & 170 & 646 & 85 & 544 & 68 \\
\hline Ephemeroptera & 17 & - & 17 & - & - & - & 391 & 391 & - & 34 & 102 & - \\
\hline Trichoptera & - & - & 17 & - & - & $=$ & 34 & - & - & - & 34 & - \\
\hline Diptera Chironomidae & 323 & 136 & 527 & 986 & 2244 & 1258 & 41548 & 935 & 2346 & 714 & 6460 & 306 \\
\hline Diptera Ceratopogonidae & - & $\cdot$ & 17 & 17 & 68 & - & - & $\$ 1$ & 34 & - & 51 & 17 \\
\hline Total & 6979 & 0966 & 1713 & 7404 & 76885 & 7642 & 570418 & 39389 & 65875 & 25636 & 91494 & 32708 \\
\hline
\end{tabular}


Table 2. Percentage values of the zoological groups found in littoral sand of Lake Bracciano

\begin{tabular}{|c|c|c|c|c|c|c|c|c|c|c|c|c|}
\hline Stations & 1 & 2 & 3 & 4 & 6 & 7 & 9 & 1 & 0 & 1 & 1 & 2 \\
\hline Turbellaria & 6.7 & 9.1 & 0.9 & 1.4 & 1.0 & 1.2 & 0.2 & 6.6 & 0.8 & 2.4 & 1.9 & 4.6 \\
\hline Nematoda & 33.0 & 4.5 & 395 & 609 & 17.0 & 9.1 & 51.1 & 5.1 & 664 & 357 & 38.3 & 6.0 \\
\hline Oligochaeta & 49.0 & 85.0 & 29.5 & 23.4 & 79.4 & 31.1 & I8 8 & 65.9 & 14.2 & 27.2 & 342 & 757 \\
\hline Hirudinea & & $*$ & 02 & - & & & & & - & 0.07 & & \\
\hline Gastropoda & & & & & . & 0.06 & 0.04 & 0.3 & 02 & 03 & 0.I & \\
\hline Bivalvia & $=$ & 0.03 & . & & & - & 0.01 & 0.04 & $=$ & & - & 0.2 \\
\hline Hydracarina & 0.8 & 0.03 & 2.5 & 0.4 & 03 & 183 & 0.05 & 1.7 & 4.0 & 21 & 0.6 & 4.2 \\
\hline Cladocera & 1.0 & 0.1 & 2.0 & 0.7 & 0.1 & 0.6 & 1.0 & 0.9 & 0.2 & 2.6 & 3.0 & 1.9 \\
\hline Copepoda & 7.7 & 0.3 & 14.5 & 7.3 & 07 & 15.2 & 192 & 14.6 & 7.9 & 251 & 134 & 37 \\
\hline Ostracoda & 0.6 & 0.4 & 3.8 & 1.0 & 0.08 & 18.6 & 1.8 & 1.0 & 1.6 & 12 & 0.7 & 34 \\
\hline Amphipoda & - & 0.2 & 2.3 & 1.3 & 0.08 & 1.2 & 0.4 & 0.4 & 1.0 & 03 & 0.6 & 0.2 \\
\hline Ephemeroptera & 0.06 & - & 0.2 & $=$ & & . & 0.07 & 1.0 & - & () I & 0.1 & - \\
\hline Trichoptera & & - & 0.2 & - & & - & 0.01 & - & & . & 0.04 & - \\
\hline Diptera Chironomidae & 1.2 & 03 & 4.5 & 3.6 & 1.3 & 4.6 & 7.3 & 2.4 & 3.6 & 2.8 & 70 & 0.9 \\
\hline Diptera Ceratopogonidae & - & - & 0.2 & 0.06 & 0.04 & - & - & 0.1 & 0.05 & - & 006 & 0.05 \\
\hline
\end{tabular}

Oligochaetes is the predominant group both qualitatively and quantitatively (Tables 1-2-3). Naidids comprise most of the oligochaete species (18), followed by tubificids (5) and aeolosomatids (1). All tubificid species found during this study had already been recorded in the lake in previous investigations on littoral and profundal macrobenthos (NOCENTINI, 1973, BAZZANTI, 1981; BONACINA et al., 1992), while most part of the naidid species have been identified in the lake for the first time during this study and it is probably related to both a major presence of these worms in marginal sediments and a more extensive sampling. The distribution of the species at the stations have shown considerable differences because some of them were widely colonized by oligochaetes (stations 11,8 and 7 with 22,20 and 18 taxa respectively), while in several others a low number of taxa was observed (at st. 2 only 4).

Quantitatively the group reached its highest densities at station 5 (a.m.: 140420 ind. $\mathrm{m}^{-2}, 73.4 \%$ of the total fauna) where Enchytraeidae constituted nearly the total of the oligochaetes (95\%), and then at station 7 (a.m.: 107270 ind. m $^{2}$, representing only $18.8 \%$ of the total fauna) mainly due to high abundances of some naidids (Chaetogaster diastrophus, Amphychaeta leidygii and Nais elinguis). Other stations have shown presences of oligochaetes remarkably lower except for st. 2 (a.m.: 43367 ind. $\mathrm{m}^{-2}$ ) characterized by high abundances of Enchytraeidae (78\% of the total oligochaetes). This latter group, immature tubificids with hair chaetae and Chaetogaster diastrophus have found to be the dominant taxa, present everywhere (Tab. 3). Moreover, naidids have shown densities higher than tubificids in 7 of the 12 stations (from st. 2 to st. 8).

Nematoda were the other largely dominant component. Exceptionally high densities of these organisms characterized the station 7 (a.m.: 201652 ind. $m^{-2}$, the highest value of the entire study), but high abundances were observed also in some other stations (9, 11 and 5, Tables 1 and 2). The percentages of the group showed a trend inversely related to that of the oligochaetes $(r=-0.80, p<0.01)$. This inverse correlation, already observed in both Lake Vico and Lake Albano, certainly points to opposite ecological role of the two groups, a phenomenon that still awaits explanation, mainly as a consequence of scanty data on the ecological requirements of nematodes in lacustrine waters. Nematoda, identified in Lake Bracciano for the first time, comprise several taxa (18) extensively distributed along the shores. Theristus setosus, Tobrilus stefanski and Ethmolaimus pratensis represent the dominant species (Tab. 3). Secondly, some other species (Morzhystera stagnalis, Tripyla glomerans, Chromadorita leuckarti displayed both wide distribution and considerable densities almost at some of the colonized stations. A tendency of nematodes toward major dispersion along the shores in comparison to oligochaetes (Tab. 3) is another aspect already recorded in other lakes (Albano and partly Vico) and which could represents a further indication of a different relationship of the two faunal groups with the sediments from both the spatial and the trophic points of view.

Copepoda (13\% of the total fauna, range at the stations: $0.3-$ $25.1 \%$ ), constitute the third large component of the community. As shown in Tab. 2, the higher percentages were found in stations located in only one part of the lake (st. 6-7-810- 11) and the maximum densities at st. 7 (109599 ind. $\mathrm{m}^{-2}$ ). Harpacticoida, which are mainly associated with sandy substrata, represented in densities the dominant copepods, but also cyclopids, characterized by species which inhabit different freshwater environments and types of substrata, displayed a substantial although localized presence (Tab. 3).

Other crustaceans showed a non secondary qualitative and quantitative presence in the lake. Among them, Ostracoda (6 taxa, $1.7 \%$ of the total fauna), Cladocera ( 9 taxa, $1 \%$ of the 
total fauna) and Amphipoda (Echinogammarus sp.), the latter found in such densities only in the sandy littoral of Lake Albano (MASTRANTUONO, 1995).

Chironomids attained in Lake Bracciano very low percentages ( $5 \%$ of the total fauna, range: $0.3 \%-7 \%$ ) and abundances with the sole exception of st. 7 (41548 ind. $\mathrm{m}^{-2}$ ). All genera, excluding Paratanytarsus sp., Einfeldia sp. (?) and Paracladopelrna sp., had already been found in the lake. Polypedilum breviantennatum is the only chironomid present everywhere and also the most abundant one. Other Chironominae (Einfeldia sp. (?), Cryptochironornus sp.,
Paracladopelrna sp. and Stictochironomus sp.) displayed wide distribution but high densities only in some stations, while Orthocladiinae and Tanytarsini showed reduced presence.

Of other faunal groups Turbellaria (1.5\% of the total fauna) and Hydracarina (1\%) contribute to forming a diversified community structure. Gastropods occurred instead in only one sector of the lacustrine perimeter (stations from 6 to 11), while all the remaining faunal groups showed occasional presence.In order to test the degree of similarity among stations PSc analysis was applied (calculated on the annual mean densities of the taxa). The cluster representation of the PSc matrix (Fig.

Table 3. List of the identified taxa and densities (annual mean, ind. m-) at the sampling stations of Lake Bracciano.

\begin{tabular}{|c|c|c|c|c|c|c|c|c|c|c|c|c|}
\hline Stations & l & 2 & 3 & 4 & 5 & 6 & 7 & 8 & y & 10 & 11 & 12 \\
\hline Turbellaria & 1819 & 4641 & 102 & 374 & 1717 & 340 & 935 & 2618 & 544 & 629 & 1717 & 1513 \\
\hline \multicolumn{13}{|l|}{ Nematoda } \\
\hline Monhystera stagnalis Hastian & - & - & 17 & - & 17 & 17 & 42194 & 17 & 578 & 306 & 36.38 & 17 \\
\hline Theristus fevensis Schuurmann-Stekkoven & $\cdot$ & $\cdot$ & 119 & 187 & 5474 & 34 & $\cdot$ & - & 748 & 68 & 85 & - \\
\hline Theristus setosus (Butschli) & 4284 & 1717 & 3128 & 14382 & 11254 & 1598 & 158899 & 561 & 21760 & 918 & 14229 & 1377 \\
\hline Aphanolaimus aquaticus Dadav & 34 & - & 17 & - & 136 & 68 & 102 & 17 & 289 & 17 & - & 68 \\
\hline Ethmolaimus pratensis Le Man & 68 & $5 t$ & 119 & 612 & 748 & 289 & 72386 & 935 & 578 & 1105 & 1428 & 68 \\
\hline ('hromadorita leuckarti (De Man) & 34 & 17 & 17 & $\$ 27$ & 629 & 34 & 6069 & $\cdot$ & 289 & 51 & 391 & $5 i$ \\
\hline Tripyla filicaudata De Men & - & - & - & - & 918 & . & - & - & 1411 & - & - & - \\
\hline Tripyla glomerans Bastian & 2176 & 153 & 34 & $\cdot$ & 289 & 221 & 4352 & 306 & 306 & 170 & 1853 & 17 \\
\hline Tobrilus pellucidus (Bastiar) & 17 & - & - & - & 6851 & 17 & 1547 & $\cdot$ & 425 & 17 & 340 & - \\
\hline Tobrilus stefanski (Micoletski). & 2159 & 323 & 1139 & 969 & 952 & 17 & 4845 & 119 & 13736 & 389.3 & 119.34 & 187 \\
\hline Ironus tenuicaudatus De Man & 17 & 17 & - & - & 1938 & $\cdot$ & 204 & $\cdot$ & 85 & $\cdot$ & 459 & 17 \\
\hline Mononchus aquaticus Coetzee & - & $\cdot$ & - & - & 17 & - & $\cdot$ & - & - & - & & 85 \\
\hline Mylonchulus sigmaturus (Cobb) & - & + & $\cdot$ & - & $\cdot$ & $\cdot$ & $\cdot$ & $\cdot$ & 34 & 34 & $\cdot$ & 17 \\
\hline Paractinolaimus macrolaimus (De Man) & $\cdot$ & $\cdot$ & $\cdot$ & - & $\cdot$ & 17 & $\cdot$ & $\cdot$ & $\therefore$ & $\therefore$ & $\cdot$ & - \\
\hline Tobrilus sp. & - & $\cdot$ & $\cdot$ & - & $\cdot$ & $\cdot$ & $\cdot$ & - & 2890 & 2414 & 51 & - \\
\hline Plechus sp. & $\cdot$ & & $\cdot$ & $\cdot$ & 85 & - & $\cdot$ & - & 85 & 34 & 34 & - \\
\hline Dorylaimina gen $\mathrm{sp}$ & 119 & 17 & 34 & 17 & 799 & 204 & 1054 & 51 & 204 & 119 & 561 & 51 \\
\hline Chromadorida undet. & $\cdot$ & - & $\cdot$ & $\cdot$ & $\cdot$ & $\cdot$ & $\cdot$ & $\cdot$ & 357 & $\cdot$ & - & $\cdot$ \\
\hline \multicolumn{13}{|l|}{ Oligochaeta } \\
\hline Aeolosoma hemprichi Ehremberg & 340 & $\cdot$ & $\cdot$ & - & 2482 & 493 & 2601 & 238 & 867 & 969 & 561 & 17 \\
\hline Chaetogaster diastrophus (Gruithuisen) & 1309 & 2295 & 374 & 119 & 1734 & 4726 & 45713 & 7531 & 1649 & 595 & 6460 & 901 \\
\hline Chaetogaster diaphanus (Gruithuisen) & - & $\cdot$ & 17 & - & 17 & 17 & 170 & 340 & $\cdot$ & 102 & 34 & - \\
\hline Amphichaeta leydigii Tauber & - & - & 289 & 2397 & 357 & 34 & 30379 & 51 & 952 & 17 & 34 & - \\
\hline Uincinais uncinala (Oestedi) & 17 & - & $\cdot$ & $\cdot$ & $\cdot$ & $\cdot$ & - & - & - & & 34 & - \\
\hline Pristina aequiseta Bourne & - & - & - & - & 119 & 34 & 17 & 51 & $\cdot$ & 51 & - & - \\
\hline Pristina longiseta Ehremberg & - & - & - & - & 17 & $\cdot$ & $\cdot$ & 17 & - & 204 & \pm 42 & 51 \\
\hline Pristina foreli Piguet & 34 & - & - & - & - & 34 & 17 & 102 & - & 102 & 340 & $3+$ \\
\hline Aulophorus sp. & - & - & - & - & - & - & $\cdot$ & $\cdot$ & $\cdot$ & 119 & 34 & - \\
\hline Derodigitata Udekem & - & + & $\cdot$ & - & - & - & $\cdot$ & - & - & - & 34 & - \\
\hline Stylaria lacustris (L.) & - & - & - & - & - & - & - & $\cdot$ & - & 17 & - & - \\
\hline Nais communs Piguet & - & - & - & - & - & 17 & - & 102 & $\cdot$ & - & 34 & - \\
\hline Nais variabilis Piguet & - & - & 119 & 272 & 102 & 187 & 34 & 187 & 357 & 289 & 340 & - \\
\hline Nais christinae Kasparzak & 85 & - & 187 & 204 & 34 & 17 & 187 & 1054 & - & 187 & 187 & - \\
\hline Nais pardalis Piguet & $\cdot$ & - & $\cdot$ & - & - & 17 & 4284 & 85 & - & - & - & - \\
\hline Nais bretscheri Michaelsen & 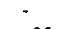 & - & - & - & - & 34 & 1054 & 153 & - & - & 51 & \\
\hline Nais elinguis Müller & 85 & $\cdot$ & - & - & 170 & 102 & 11322 & 4913 & - & 68 & 4386 & 68 \\
\hline Nais simpler Piguet & - & - & - & 17 & 17 & - & - & - & - & - & 17 & - \\
\hline Nais barbata (Muller) & - & - & - & - & 102 & - & 1037 & 510 & - & 1.36 & 170 & - \\
\hline Branchiura sowerbyi Beddard & - & - & 17 & - & $\cdot$ & - & 34 & 68 & in & - & 51 & - \\
\hline Psammonyctes barbatus (Gube) & - & - & - & - & - & - & 85 & 51 & 510 & - & 136 & - \\
\hline Potamothrix heuscheri (Bretscher) & 102 & - & - & $\cdot$ & $\cdot$ & - & - & - & . & - & - & - \\
\hline Potamothrix hammoniensis (Michaelsen) & 136 & - & - & - & - & 68 & 102 & 102 & . & $\cdot$ & 102 & 34 \\
\hline Limnodrilus hoffmeisteri Claparede & 17 & 17 & - & - & 119 & 17 & 5066 & 1989 & - & 2125 & 6341 & 187 \\
\hline Imm tubificids with hair chactae & 4403 & 1003 & 204 & 17 & 2448 & 2499 & 4981 & 6936 & 4590 & 1309 & 1084 & 2754 \\
\hline Enchytraeidac & 6681 & 40052 & 2244 & 3383 & 132702 & 306 & 187 & 1479 & 425 & 697 & 459 & 20706 \\
\hline \multicolumn{13}{|l|}{ Hirudinea } \\
\hline Erpobdella sp & * & - & 17 & $\cdot$ & $\cdot$ & - & $\cdot$ & - & - & 17 & - & - \\
\hline \multicolumn{13}{|l|}{ Gastropoda } \\
\hline Theodoxus fluviatilis $(L)$ & - & - & - & - & - & - & 153 & 51 & 17 & $\cdot$ & - & - \\
\hline Bithynia tentaculata $(I,)$. & $\cdot$ & - & - & - & $\cdot$ & - & 34 & - & 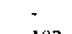 & 68 & 102 & - \\
\hline Lymnaea peregra (Müller) & - & - & - & - & - & $\cdot$ & 34 & 34 & 102 & - & - & \\
\hline Viviparus sp & - & - & - & - & - & 17 & & 17 & - & - & . & - \\
\hline \multicolumn{13}{|l|}{$\begin{array}{l}\text { Bivalvia } \\
\text { a }\end{array}$} \\
\hline Pisidium sp. & - & 17 & - & - & $\cdot$ & - & 34 & 17 & - & - & - & 5 \\
\hline
\end{tabular}


Table 3. continued

\begin{tabular}{|c|c|c|c|c|c|c|c|c|c|c|c|}
\hline \multicolumn{12}{|l|}{ Hydracarina } \\
\hline Lebertia sp. & $\cdot$ & $\cdot$ & $\cdot$ & - & 17 & - & 221 & - & 272 & * & 187 \\
\hline Limnesia sp. & - & - & - & 34 & $\cdot$ & - & - & - & - & - & 17 \\
\hline Neumania sp & - & $\cdot$ & 17 & - & - & - & - & - & 34 & - & - \\
\hline Arrhenurus sp. & - & - & $\cdot$ & - & - & 34 & - & - & - & - & - \\
\hline Oribatei & 204 & 17 & 272 & 85 & 578 & 5032 & 51 & 663 & 2380 & 544 & 306 \\
\hline \multicolumn{12}{|l|}{ Cladocera } \\
\hline Bosmina longirostris (O.F.Muller) & 17 & 17 & 68 & 51 & $\cdot$ & - & - & 34 & - & 306 & 17 \\
\hline Iliocryptus agilis Kurz & - & - & $\cdot$ & - & - & - & 238 & $\cdot$ & - & 17 & - \\
\hline Alonella excisa (Fisher) & 85 & $\cdot$ & 51 & - & - & $\cdot$ & - & 34 & 34 & $\cdot$ & - \\
\hline Chydonus sphaericus (O.F Maller) & 51 & 34 & - & 34 & - & 34 & $\cdot$ & 51 & 34 & 17 & - \\
\hline Monospilus dispar Sars & - & - & 17 & - & - & - & 68 & - & - & 119 & 85 \\
\hline Leydigia acanthocercoides (Fischer) & - & $\cdot$ & - & - & - & - & 1343 & - & - & - & 136 \\
\hline Acroperus harpae (Baird) & 51 & 17 & 34 & 85 & - & 85 & + & 85 & - & 34 & 17 \\
\hline Alona rectangula Sars & 51 & - & 34 & - & 17 & - & 1071 & 17 & - & 17 & 2329 \\
\hline \multicolumn{12}{|l|}{ Copepoda } \\
\hline Macrocyclops albidus (Jurine) & . & - & - & $\cdot$ & - & - & 17 & 17 & - & - & - \\
\hline Eucyclops serrulatus (Fisher) & $\cdot$ & 17 & 918 & 255 & - & - & $\cdot$ & - & - & - & $\cdot$ \\
\hline Eucyclops macruroides (Lilljegorg) & 425 & - & $\cdot$ & 17 & 17 & - & 204 & - & - & 68 & - \\
\hline Paracyclops fimbriatus (Fisher) & 34 & - & 425 & 1037 & - & - & 1666 & $\$ 1$ & - & 782 & 4539 \\
\hline Diacyclops bisetosus (Rehberg) & 102 & - & $\cdot$ & - & $\cdot$ & $\cdot$ & - & 408 & 17 & - & - \\
\hline Harpacticoida & 1530 & 119 & 357 & 680 & 1207 & 4216 & 107712 & 5270 & 5185 & 5593 & 7701 \\
\hline \multicolumn{12}{|l|}{ Ostracoda } \\
\hline Danwinula stevensoni (Br. \& Rob.) & 68 & 102 & 391 & 187 & 17 & 2601 & 5916 & 136 & 901 & 102 & 425 \\
\hline Cyprioophralmica (Jurine) & - & - & - & - & - & 374 & - & 51 & 17 & - & - \\
\hline Cypridopsis vidua (O.F.Muller) & $\cdot$ & $\cdot$ & - & $\cdot$ & $\cdot$ & 102 & 51 & 68 & - & 136 & - \\
\hline Lymnocythere sp. & 34 & 34 & 51 & 51 & 119 & 2023 & 1479 & 85 & 85 & 34 & - \\
\hline Ilyocypris $\mathrm{sp}$ & 17 & 68 & - & - & - & 34 & 2720 & 17 & - & 17 & 170 \\
\hline Candona sp. & 34 & 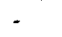 & - & 34 & - & 17 & 136 & 34 & 34 & 17 & 34 \\
\hline \multicolumn{12}{|l|}{ Amphipoda } \\
\hline Echinogammarus sp. & - & 85 & 272 & 357 & 136 & 323 & 2465 & 170 & 646 & 85 & 544 \\
\hline \multicolumn{12}{|l|}{ Ephemeroptera } \\
\hline Boetis sp. & - & - & 17 & - & - & - & - & - & - & - & - \\
\hline Caenis sp. & 17 & - & - & - & - & - & 391 & 391 & - & 34 & 102 \\
\hline \multicolumn{12}{|l|}{ Trichoptera } \\
\hline Ecnomus tenellus (Rambur) & - & - & 17 & - & - & $\cdot$ & 34 & - & - & - & 17 \\
\hline \multicolumn{12}{|l|}{ Diptera Chironomidae } \\
\hline Psectrocladius sp. & - & - & - & - & - & - & $\therefore$ & 17 & 17 & - & - \\
\hline Cricotopus SP & - & - & - & - & 901 & 102 & 1496 & 510 & - & 272 & 238 \\
\hline Orthocladiinae indet. & 51 & - & 17 & 17 & 17 & 17 & - & 119 & - & 119 & 17 \\
\hline Procladius sp & $\cdot$ & - & - & - & - & $\cdot$ & 289 & - & - & - & 136 \\
\hline Pentaneurini & 17 & - & $\cdot$ & 17 & - & - & - & $\cdot$ & - & - & - \\
\hline Tanvtarsus sp. & - & - & 17 & $\cdot$ & 34 & $\cdot$ & 833 & 34 & - & - & 34 \\
\hline Cladotanvtarsus sp. & - & - & - & 17 & 204 & 17 & 17646 & $\cdot$ & - & - & 34 \\
\hline Paratendipes sp & - & - & 34 & - & $\cdot$ & 119 & 391 & - & 238 & - & - \\
\hline Paratanyiarsus sp. & - & $\cdot$ & - & - & - & - & 34 & - & $\cdot$ & - & - \\
\hline Stictochironomus sp. & 34 & 51 & 34 & 85 & 459 & 85 & 1428 & - & 170 & - & 1853 \\
\hline Endochironomus sp & - & - & - & - & + & - & 17 & - & - & - & 17 \\
\hline Polypedilum breviantennatum Chernovski & 85 & 51 & 136 & 119 & 221 & 459 & 11679 & 102 & 1003 & 187 & 3536 \\
\hline Polypedilum bicrenatum $g$ & 68 & 17 & - & - & - & - & 17 & - & - & - & 17 \\
\hline Dicrotendipes nervasus gr. & - & - & $\cdot$ & 17 & $\cdot$ & - & $\cdot$ & - & - & 34 & - \\
\hline Einfeldia sp. (?) & - & 17 & 187 & 629 & 340 & 391 & 3400 & 102 & 680 & - & 204 \\
\hline Cryptochironomus sp. & 68 & - & 51 & 51 & 34 & 34 & 3196 & 34 & 153 & 34 & 357 \\
\hline Pamcladopelmo sp. & $\cdot$ & - & 34 & 17 & 34 & 34 & 986 & 17 & 85 & 68 & 34 \\
\hline Parachironomus sp. & - & - & - & 17 & $\cdot$ & - & - & - & - & $\cdot$ & - \\
\hline Cladopelma Jaccophila g. & - & - & . & - & - & - & 153 & - & - & - & - \\
\hline Diptera Ceratopogonidae & - & - & 17 & 17 & 68 & & - & 51 & 34 & . & 51 \\
\hline
\end{tabular}

5) displayed a dishomogeneous association of the stations, unrelated to their spatial localization.

Four groups of stations were identified, three of which characterized by a similarity lying between $50 \%$ and $60 \%$. Only the stations 2-5-12 were found to be very similar and clearly different from the others. In order to account, at least partially, for this unexpected aggregation among distant stations, PSc analysis was applied also to grain size data (based on annual mean values of all four categories). As can be observed in Fig. 5 cluster representation shows some partial but interesting correspondences with PSc analysis on faunal data. The comparison highlights the existencc of three groups (principally the stations 2-5-12 but also the stations 1-34 and 7-9) which in both cases proved to be associated. It thus seems possible to consider sediment composition as one important factor that can influence the structure of the community as a 

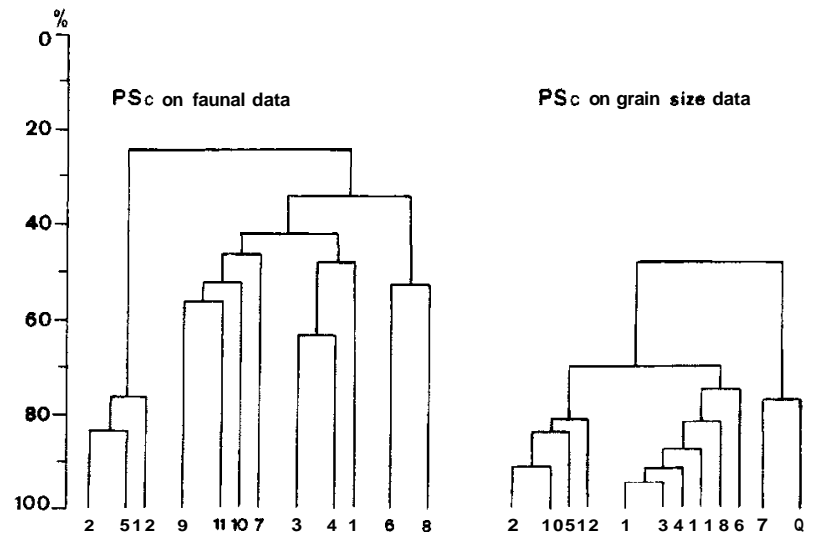

FIGURE 5. Cluster representation of PSc analysis on faunal data (annual mean densities of the taxa) and on grain size data (annual means).

whole, while the attempt to identify single species or faunal groups more strongly influenced by grain size composition using PSc analysis gave results not completely reliable. As a matter of fact, the complex issue of relations between sediment composition and benthic community, which has been studied by several authors from different viewpoints (JUGET, 1979; COLE \& WEIGMANN,'1983; McMURTRY et al, 1983; VODOPICH \& COWELL, 1984; WINNELL \& JUDE, 1984; MASTRANTUONO \& BALDETTI, 1996b) unfortunately produced discordant elements of evaluation and the ensuing wide-ranging discussion is still far from indicating any resolution. So, in spite of the obvious existence of these relations, it appears very difficult explain at present how sediment composition influences the organisms who live in.

\section{DISCUSSION}

The role that sediment-associated communities play in the evaluation of trophy or of environmental quality of a lake has been defined in the specialized literature from many years by a large

Table 4. Some significant parameters of the zoobenthos living in littoral sand of Lake Bracciano in an evaluation of environmental quality. $(\mathrm{O} / \mathrm{O}+\mathrm{C}$ : Wiederholm index $)$.

$\begin{array}{lrrrrrrrrrrrr}\text { Stations } & 1 & 2 & 3 & 4 & 5 & 6 & 7 & 8 & 9 & 10 & 11 & 12 \\ & & & & & & & & & & & & \\ \text { Number oftaxa } & 42 & 27 & 45 & 39 & 49 & 51 & 66 & 61 & 48 & 57 & 67 & 37 \\ \text { Diversity (H) } & \mathbf{3 . 4} & \mathbf{1 . 3} & \mathbf{3 . 8} & \mathbf{2 . 8} & \mathbf{1 . 8} & \mathbf{3 7} & \mathbf{3 . 5} & \mathbf{3 . 8} & \mathbf{3 . 5} & \mathbf{4 . 2} & \mathbf{4 . 1} & \mathbf{2 . 3} \\ \text { Evenness } & \mathbf{0 . 6} & \mathbf{0 3} & \mathbf{0 . 7} & \mathbf{0 . 5} & \mathbf{0 . 3} & \mathbf{0} 7 & \mathbf{0 . 6} & \mathbf{0 . 6} & \mathbf{0 . 6} & \mathbf{0 . 7} & \mathbf{0 . 7} & \mathbf{0 . 4} \\ \text { O/O+C (\%) } & \mathbf{9 3 . 5} & \mathbf{9 6 . 1} & \mathbf{6 9 . 6} & \mathbf{7 5 . 4} & \mathbf{7 7 . 5} & \mathbf{8 6 . 8} & \mathbf{7 2 . 0} & \mathbf{9 6 . 3} & \mathbf{7 9 . 2} & \mathbf{8 9 . 8} & \mathbf{8 2 7} & \mathbf{9 3 0}\end{array}$

body of evidences (SAETHER, 1979, 1980; KANSANEN et al., 1984; CROZET, 1985; SARKKA, 1992, 1994; GERSTMEIER, 1989: PETRIDIS, 1993: RAZZANTI et al, 1994). The extension of this approach also to littoral nTUONO, 1995) which has been made to verify the application of some evaluation criteria (bioindices and bioindicators) widely tested for sublittoral and profundal zoobenthos.

Oligochaeta and Diptera Chirorzomidae, the dominant organisms in the sediments, represent the main organisms used for quality monitoring. However, in marginal areas the community structure is more complex due to the presence of several faunal groups. The complexity of the system, associated with less restrictive environmental conditions, makes it difficult to identify significant evaluation parameters. The investigations I have carried out so far on this biocoenosis (literature cited) allow a combined series of simple parameters to be selected that proved some indication of quality with sufficient reliability as regards both the sampling site and the entire lacustrine perimeter.

A summary of some of these parameters is given in Tab. 4. They consist of bioindices (species richness, Shannon diversity, evenness, Wiederholm index) and density values (expressed as annual means) of bioindicator taxa. In addition, a simple index (NIT ratio) recently proposed will be used (MASTRANTUONO, 1995).

Species richness has a meaning especially if we consider the total number of identified taxa, which in Lake Bracciano (103) is partly satisfactory if we take into account the considerable size of the lake. The number of taxa at the stations (Tab. 4) showed a good longshore dispersion, although greater species richness can be observed in the North of the lake (st. 7-8-1011, range: 37-66 taxa), while several stations (1-2-3-4-5) located in the large beaches of the southern part are characterized by a lower number of taxa (range: 27-49). A particularly low value was observed only at st. 2 (27 taxa), probably as a consequence of the large quantitative prevalence of Erzchytraeidae, which strongly affect the community composition. The values of $\mathrm{H}$ and evenness, that proved to be a good parameter of evaluation, were found to be relatively high everywhere (Tab. 4): $\mathrm{H}$ actually reached values higher than 3.4 in 8 of the 12 stations and also higher than 4 in two of them. Only the stations $2-5-12$

were characterized by low diversity and evenness due to the large quantitative predominance of Enchytraeidae. If we examine these first observations referring to species composition, the commu-nity appears to be, excluding a few stations, quite well diversified and quantitatively well structured, with some sites characterized by excellent situation. 
Table 5. Comparison of some parameters of evaluation in the studied lakes. Tub ind.: indicators tubificids. Diversity and evenness are expressed as mean value among stations. Data of Lake Vico refers to a recent, still unpublished study.

\begin{tabular}{|c|c|c|c|c|}
\hline Lakes & Nemi & Albano & Vico & Bracciano \\
\hline number of taxa & 65 & 79 & 100 & 103 \\
\hline $\begin{array}{l}\text { Diversity (H) } \\
\text { evenness }\end{array}$ & $\begin{array}{l}2.7 \\
0.5\end{array}$ & $\begin{array}{l}3.2 \\
0.6\end{array}$ & $\begin{array}{l}3.0 \\
0.6\end{array}$ & $\begin{array}{l}3.2 \\
0.6\end{array}$ \\
\hline $\mathrm{N} / \mathrm{T}$ ratio & 2.0 & 2.6 & 2.4 & 3.6 \\
\hline Total fauna (range, ind $/ \mathrm{m}^{2}$ ) & & 8789-29257 & 27314-94381 & 11719-570418 \\
\hline Tub.ind of eutrophy $\left(\mathrm{ind} / \mathrm{m}^{2}\right)$ & & $884-4658$ & $536-12376$ & $17-17527$ \\
\hline $\begin{array}{l}\text { Tub. ind. of eutrophy (\%) } \\
\text { number of molluscan taxa }\end{array}$ & $\begin{array}{c}1.6-71.9 \\
0\end{array}$ & $\begin{array}{c}3.0-27.0 \\
4\end{array}$ & $\begin{array}{c}3.0-13.1 \\
5\end{array}$ & $\begin{array}{c}0.06-191 \\
5\end{array}$ \\
\hline number of cladoceran taxa & 1 & 5 & 7 & 8 \\
\hline trophic level & eutrophy & mesotrophy & mesotrophy & mesotrophy \\
\hline
\end{tabular}

of tubificid species, calculated only on all the identified oligochaete taxa). My observations point to a tendency towards a reduction of naidid species (typical of littoral zones) and an increase of tubificid species (more typical of profundal sediments) with increasing trophy. The interest of such a simple qualitative ratio may be related to the observations of other authors who evidenced increasing densities of tubificids in littoral zones subject to eutrophication (SARKKA, 1983). The N/T ratio in Lake Bracciano (3.ó), the highest so far observed in lakes of Central Italy (Tab. 5 ), seems indicative of a non alteration of

The total densities of invertebrates, which can provide general but interesting information on the productive level of the substrate, covered a wide range (11719-570418 ind. $\left.\mathrm{m}^{-2}\right)$ varying from values typical of oligotrophic condition (st. 3) to exceptionally high values (st. 7-5-1 1), that can be considered characteristic of a productive situation. But, in the majority of stations the observed densities were typical of a rich community indicative of a mesotrophic condition (range: 25636-65875 ind. $\mathrm{m}^{2}$ ), as can be seen also from the comparison with previously collected data for lakes in Central Italy (Tab. 5 and, for detailed data, see also literature cited).

Oligochaeta, both as group and species, have so far proved to be the best bioindicator taxa. Moderate density values (annual mean) of these organisms were observed in most of the stations except for st. 5 and 7 (Tab. 3). Three species of tubificids (Limnodrilus hoffmeisteri, Potarnothrix heuscheri, Potamothrix hammoniensis) and one naidid (Nais elinguis) considered in high densities as indicators of eutrophy (LANG \& LANG-DOBLER, 1979; LEARNER 1979; MILBRINK, 1983; LANG, 1984; JONASSON. 1984; BAZZANTI \& SEMINARA, 1985) are found in Lake Bracciano. The immature tubificids, belonging to Potamothrix species were relatively abundant (Tab. 3) in almost all stations, while both N. elinguis and I. hoffrneisteri displayed relatively high densities only in a few stations and were completely absent in several others. In any case, the presence of each species of bioindicator oligochaetes was found to be less than 20000 ind. $\mathrm{m}^{-2}$ (annual mean) and $25 \%$ of the total fauna, that are the values proposed, on the grounds of all my previous studies, as the limit for identifying an eutrophic condition in a littoral site.

A further indication of quality level in sandy shores can be represented by the NIT ratio (number af naidid species/number the natural composition of the oligochaete community. A separate discussion should be devoted to the notable presence in these sediments of Oligochaeta Enchytraeidae, whose trophic role is far from having been clarified, although some authors (MAITLAND \& HUDSPITH, 1974; WHITESIDE \& LINDEGAARD, 1982) have recognized that this group, for its abundance, can be considered an important component in littoral sediments.

Exceptionally low densities and percentages of chironomids have been recorded in the lake. Also the presence of Procladius sp., the only chironomid indicator of eutrophy (SAETHER, 1980) found in the community, was scarce and rare. The low densities of these dipterans cause a rise in the values of the $\mathrm{O} / \mathrm{O}+\mathrm{C}$ index (Oligochaeta density/Oligochaeta + Chironomidae density, WIEDERHOLM, 1980) which exceeded $90 \%$ in some stations (1-2-8-12) (Enchytraeidae density was excluded from the computation as being completely unrelated to the formula of the index). Such situation supports some observations already emerged in my previous analyses that indicated the reduced importance of this index for sandy sediments. where chironomids have revealed quantitative presence strongly variable. But, in spite of the low abudances of chironomids observed in the lake, the high number of chironomid taxa (19) must be considered a positive element for the quality evaluation.

With reference to bioindicators, it must be emphasized the positive presence of molluscan taxa. As extensively discussed in a previous paper (MASTRANTUONO, 1995) several studies have clarified the role of these organisms as bioindicators of good quality mainly in sublittoral and profundal sediments (CLARKE, 1979a, 1979b; MOUTHON, 1981, 1986, 1992; SAVAGE \& GAZEY, 1987). Although 
the abundance of these organisms is generally low in lacustrine sandy littoral, their finding is in any case significant because in Lake Bracciano have been found 5 molluscan taxa (4 gastropods and 1 bivalve), a number that characterizes other lakes in good environmental conditions (Tab. 5), while only one taxa was recorded in the eutrophic Lake Nemi.

Another interesting bioindicator group is represented by cladocerans, whose role in water quality evaluation have been widely stressed for the zoobenthos associated with submerged macrophytes (BERZINŠ \& BERTILSSON, 1989; MASTRANTUONO, 1990, 1991). However, the presence of numerous species in sandy shores of the lakes Albano, Vico and Bracciano, and of only one cladoceran (Chydorus sphaericus), considered as indicator of high trophy, in the eutrophic Lake Nemi (Tab. 5), point to a possible importance of these organisms also in this substrate.

A further positive indication is also the considerable abundance in the lake of some nematode species (Theristus setosus. Ethmolaimus pratensis, Chromadorita leuckarti, Aphanolaimus aquaticus, lronus tenuicaudatus and Trypila filicaudata) recorded in clear and oxygenated waters (ZULLINI, 1976, 1982; COLOMBA \& VINCIGUERRA, 1979) and of the amphipod Echinogammarus sp., considered typical of oligo-mesotrophic conditions and whose presence in the lake was already recorded (BAZZANTI. 1981).

As a synthesis. all the results referred to community parameters and to bioindicators and bioindices converge to indicate a rich and diversified community, characterized by presence of several bioindicators of good environmental condition. Although it is impossible to compare these results directly with previous investigations that concerned with zoobenthos of much deep waters associated or not with aquatic vegetation, the overall evaluation seems in good agreement with the diagnosis of mesotrophy expressed in investigations carried out in the past decade. In fact, the fauna structure described during this study may represent an indication that no considerable modifications of the water quality have occurred in the littoral. But, an observed tendency towards a lower species richness and diversity in several stations located in the wider sandy shores of the southern zone, used extensively for sporting and bathing activities, and the high densities of total fauna registered in some sites may represent early signs of possible deterioration of quality in some littoral areas of the lake and point to the need for maximum surveillance.

\section{REFERENCES}

BARBANTI, L., BONOMI, G., CAROLLO, A., CHIAUDANI, G. FERRARI, I., GERLETTI, M., NOCENTINI, A.M., RUGGIU, D., \& L. TONOLLI, 1971. Limnologia ed ecologia dei laghi di Bolsena, Bracciano, Trasimeno e Vico: situazione attuale e prevedibili conseguenze derivanti da una loro utilizzazione multipla. Ist.Ital.Idrobiol, Verbania Pallanza, 263 pp.

BAZZANTI, M., 1981. Survey of the macrobenthic community in an area of Lake Bracciano (Central Italy). Boll.Zool, 48: 295-303.

BAZZANTI, M. \& M. SEMINARA, 1985. Seasonal changes of the profundal macrobenthic community in a polluted lake. Schweiz.Z.Hydrol, 47: 57-63.

BAZZANTI, M., SEMINARA, M. \& C. TAMORRI, 1994. Depth distribution and relationships to the trophic state of sublittoral and profundal macrobenthos in Lake Vico (Central Italy). Limnologica, 24: 13-21.

BERZINŠ \& J. BERTILSSON, 1989. On limnic microcrustaceans and trophic degree. Hydrobiologia, 185: 95-100.

BONACINA, C., BONOMI, G. \& A. PASTERIS, 1992. Some remarks on the macrobenthos community of the profundal zone of the large Italian lakes. Mem.lst.Ital.Idrobiol, 50: 79106.

BRUNO, G., 1985. Bracciano sewerage system amd sewage treatment plant automatic control. Proc.Int. Congress "Lakes pollution and recovery" (ANDIS), Roma: 194-198.

CLARKE, A.H., 1979a. Gastropods as indicators oftrophic lake stages. The Nautilus, 94: 138142.

CLARKE, A.H.. 1979b. Sphaeriidae as indicators oftrophic lake stages. The Nautilus, 94: 178184.

COLE, A. \& D.L. WEIGMANN, 1983. Relationships among zoobenthos, sediments, and organic matter in littoral zones of western Lake Erie and Saginaw Bay. J. Great l,akes Res., 9: $568-581$.

COLOMBA, G. \& M.T. VINCIGUERRA, 1979. Nematodi d'acqua dolce della Sicilia. I: Nematodi dell'Anapo. Animalia, 6: 89-120.

CROZET, B., 1985. Infiuence of the sewage treatmet plant effluents on the structure of the benthic communities of Lake of Geneva. Verh. Internat.Verein.Limnol, 22: 23272331.

FERRARA, O., 1984. Struttura e dinamica della comunita zooplanctonica in un'area del lago di Bracciano (Lazio). Riv. Idrobiol: :23: 145-158.

GAGGINO, G.F., MARCHETTI, R., CAPPELLETTI, E. \& T. CALCAGNINI, 1985. La qualita delle acque dei laghi 
italiani negli anni '80. In: Inquinamento e recupero dei laghi. Atti Congr.Internat. EWPCA, ANDIS ed.: 5-44.

GERSTMEIER, R., 1989. Lake typology and indicator organisms in application to the profundal chironomid fauna of Starnberger See (Diptera Chironomidae). Arch. Hydrobiol, 116: 227-234.

JONASSON, P.M.. 1984. Oxygen demand and long term changes of profundal zoobenthos. Hydrobiologia, 115: 121-126.

JUGET, J., 1979. La texture granulometrique des sédiments et le régime alimentaire des oligochetes limicoles. Hydrobiologia, 65: 145-154.

KANSANEN, P.H., AHO, J. \& L. PMSIVIRTA, 1984. Testing the benthic lake type concept based on chironomid associations in some Finnish lakes using multivariate statistical methods. Ann. Zool. Fennici, 21: 55-76.

LANG, C., 1984. Eutrophication of Lakes Léman and Neuchatel (Switzerland) indicated by oligochaete communities. Hydrobiologia, 115: 131 - 138.

LANG, C. \& B. LANG-DOBLER, 1979. The chemical environment of tubificid and lumbriculid worms according to the pollution level of the sediment. Hydrobiologia, 65: 273-282.

LEARNER, M.A., 1979. The distribution and ecology of the Naididae (Oligochaeta) which inhabit the filter-beds of sewage-works in Britain. Wat. Res., 13: 1291-1299.

LINDEGAARD, C. \& P.C. DALL, 1988. Abundance and distribution of Oligochaeta in the exposed littoral zone of Lake Esrom, Denmark. Arch. Hydrobiol. /Suppl., 81: 533562.

LOSITO, C., 1904. Entomostraci pelagici del Lago di Bracciano. Tipografia Nazionale di G. Bertero e C., Roma.

MAITLAND, P.S. \& P.M.G. HUDSPITH, 1974. The zoobenthos of Loch Leven, Kinross, and estimates of its production in the sandy littoral area during 1970 and 1971. Proc. R. Soc. Edinb., B, 74: 219-239.

MARGALEF, R., 1957. La teoria de la information en ecologia. Mem. Real Acad. ciencias y artes de Barcelona, 32: 373-449.

MARTINI, P., 1985. The project CO.B.I.S. plants. Proc. Int. Congress "Lakes pollution and recovery" (ANDIS), Roma: 194- 198.

MASTRANTUONO, L., 1986. Littoral sand zoobenthos and its relation to organic pollution in Lake Nemi (Central Italy). Hydrobiol. Bull, 19: 171-178.

MASTRANTUONO, L., 1990. Composition and distribution of the zoobenthos associated with submerged macrophytes in Lake Albano (Italy) and environmental quality in the littoral. Riv. Idrobiol., 29: 709-727.
MASTRANTUONO, L., 1991. The zoobenthos associated with submerged macrophytes in littoral areas of LakeVico (Italy): some relations between fauna structure and water quality. Limnetica, 7: 153- 162.

MASTRANTUONO, L., 1995. The invertebrate community of littoral sandy shores in Lake Albano (Italy): fauna composition and ecological remarks. Ecol. Mecliter, 21 : 101-112.

MASTRANTUONO, L. \& C. LA ROCCA. 1988. The invertebrate fauna in sandy shores of Lake Vico (Italy): its use in a trophic evaluation of littoral sedimcnts. Ecol. Mecliter, 14: 121129.

MASTRANTUONO, L. \& P. BALDETTI, $1996 \mathrm{a}$. Composizione della comunita ad Invertebrati dei sedimenti litorali del lago di Vico (Italia Centrale) e qualita ambientale in differenti periodi di studio. $57^{\circ}$ Congresso U.Z.I., 34 .

MASTRANTUONO, L. \& P. BALDETTI, 1996b. Influenza della tessitura granulometrica dei sedimenti sulla di stribuzione dello zoobentho $s$ associato al litorale sabbio so del lago di Vi co (Italia Centrale). XII Congresso A.I.O.L., Isola di Vulcano, 18-21 settembre.

McMURTRY, M.J., RAPPORT, D.J. \& K.E. CHUA, 1983. Substrate selection by Tubificid Oligochaetes. Can. J. Fish. Aquat. Sci., 40: 1639- 1646.

MILBRINK G., 1983. An improved environmental index based on the relative abundance of oligochaete species. Hydrobiologia, 102: 89-97.

MOUTHON, J., 1981. Les mollusques et la pollution des eaux douces: ébauche d'une gamme de polluosensibilité des especes. Bij. Dierkd., 51: 250-258.

MOUTHON, J., 1986. Principes généraux pour une méthode d'appréciation de la qualité globale des sédiments lacustres a l'aide d'une analyse simplifiée des malacocénoses. Annls. Limnol, 22: 209-217.

MOUTHON J., 1992. Snail and bivalves populations analysed in relation to physico-chemical quality of lakes in eastern France. Hydrobiologia, 245: 147-156.

NOCENTINI, A.M., 1973. La fauna macrobentonica litorale e sublitorale dei laghi di Bolsena, Bracciano e Vico (Italia Centrale, Lazio). Mem. Ist. Ital. Idrobiol., 30: 97-148.

PIELOU, E.C., 1966. Species-diversity and pattern-diversity in the study of ecological succession. J. Theoret. Biol., 10: 370-383.

PETRIDIS, D., 1993. Macroinvertebrate distribution along an organic pollution gradient in Lake Lysimachia (Western Greece). Arch. Hydrobiol., 128: 367-384.

RENKONEN, O., 1938. Statistisch-okologische Untersuchungen uber die tcrrestrische Kaferwelt der 
finnischen Bruchmoore. Ann. Zool. Soc. Zool. Bot. Fenn. Vanamo. 6: 1-231.

SAETHER. O.A., 1979. Chironomid communities as water quality indicators. Holarctic Ecol., 2: 65-74.

SAETHER. O.A., 1980. The influence of eutrophication on deep lake benthic invertebrate communities. Prog Wat. Tech., 12: 161-180.

SÄRKKÄ, J.. 1983. A quantitative ecological investigation of the littoral zoobenthos of an oligotrophic finnish lake. Ann. Zool. Fennici, 20: 157- 178.

SÄRKKÄ. J., 1992. Lacustrine profundal meiobenthos as an environmental indicator. Hydrobiologia, 2431244: 333-340.

SARKKA, J., 1994. Lacustrine profundal meiobenthic oligochaetes as indicators of trophy and organic loading. Hydrobiologia, 278: 231-241.

SAVAGE, A.A. \& G.M. GAZEY, 1987. Relationships of physical and chemical conditions to species diversity and density of gastropodsin english lakes. Biol. Conserv, 42: 95-113

SNEATH P.H.A. \& R.R. SOKAL, 1973. Numerical taxonomy. Freeman \& Co., San Francisco, California, 573 pp.

SOMMANI, E., 1961. Osservazioni sulle variazioni quantitative di Entomostraci planctonici ne lago di Bracciano. Boll. Resca Piscic.Idrobiol., 16: 87-94.

VODOPICH, D.S. \& B.C. COWELL, 1984. Interaction of factors governing the distribution of a predatory aquatic insect. Ecology, 65: 39-52.

WEBER, C.T., 1973. Biological field and laboratory methods for measuring the quality of surface waters and effluents. EPA, 67014-73-001

WHITESIDE. M.C. \& C. LINDEGAARD, 1982. Summer distribution of zoobenthos in Grane Langso, Denmark. Freshwat. Invertebr. Biol., 1: 2-16.

WIEDERHOLM, T., 1980. Use of benthos in lake monitoring. J. War. Rollut. Cont. Fed., 52: 537-547.

WINNELL, M.H. \& D.J. JUDE, 1984. Associations among Chironomidae and sandy substrates in nearshore Lake Michigan. Can. J. Fish. Aquat. Sci, 41: 174-179.

ZULLINI, A., 1976. I Nematodi come bioindicatori. I. Studio di una successione. Rend. Acc. Lincei, 61:503-507

ZULLINI, A., 1982. Nematodi. Guide per il riconoscimento delle specie animali delle acque interne italiane. C.N.R., $\mathrm{AQ} / 1 / 190,117 \mathrm{pp}$. 